\title{
REVIEW OF FINANCE AND INVESTMENT IN DISASTER RESILIENCE IN THE BUILT ENVIRONMENT
}

\author{
Onaopepo ADENIYI ${ }^{\text {a,* }}$, Srinath PERERA a , Andrew COLLINS ${ }^{b}$ \\ ${ }^{a}$ Department of Architecture and Built Environment, Faculty of Engineering and Environment, North- \\ umbria University, Newcastle upon Tyne, United Kingdom \\ ${ }^{b}$ Department of Geography, Faculty of Engineering and Environment, Northumbria University, New- \\ castle upon Tyne, United Kingdom
}

Received 23 March 2015; accepted 30 November 2015

\begin{abstract}
In stark comparison to reductions achieved in the number of human casualties from disasters it is now evident that economic losses are increasing at a much higher rate. While several events contribute to economic loss from disasters, loss from built environment (property) damages and its consequential effects are significant. The overarching purpose of this paper is to systematically summarise and synthesise literature, critically discuss issues, and identify methodological problems as well as research, practice gaps and potential solutions to matters relating to financing and investment in Disaster Resilience in the Built Environment. Literature materials used for this the paper were gathered from reputable sources. As part of the findings of the study, a growing shift towards investment and enhancement of disaster resilience through the principles of corporate social responsibility and public private partnership was observed. However, many of the documented investments were made after disaster struck once or nearby.
\end{abstract}

KEYWORDS: Built environment; Disaster; Finance; Resilience; Property

SUPPLEMENTARY MATERIAL associated with this article can be found, in the online version, at http://dx.doi.org/10.3846/1648715X.2016.1185476

\section{INTRODUCTION}

Disaster refers to a "serious disruption of the functioning of a community or a society involving widespread human, material, economic or environmental losses and impacts, which exceeds the ability of the affected community or society to cope using its own resources" (UNISDR 2009), it is referred to as a natural disaster when the disruption resulted from a process or phenomenon that is regarded as a natural occurrence. Lawrence and Low (1990) described the built environment as an abstract concept used to depict the products of human building activity and that includes any physical alteration to the natural environment. The built environment should be able to absorb occasional disruptions but currently, the level of resilience in the built environment is insufficient as property damage is still among the major impacts of disasters. For instance, the huge physical damage to infrastructure,

* Corresponding author. E-mail: o.adeniyi@northumbria.ac.uk factories, power supply, processing and storage facilities, markets among others prevented the Japanese fishing industry from recovering quickly after the Great East Japan Earthquake (GEJE) (UNDP 2013). Similarly, Asgary et al. (2012)identified the significance of damage done to properties as a result of the 2010 flood in Pakistan. Pitt (2008) and Wedawatta (2013) also acknowledged the importance of the disaster resilience of business premises to business continuity after a disaster, and the consequence of the damages resulting from disasters. Among the strategies available for achieving disaster resilience in the built environment are: the use of disaster resilient construction methods, building codes, planning and construction considerations, disaster resilient design options, disaster resilient installations and construction materials (UNDP 1994; Rossetto 2007). Focusing on the built environment, the effective use of the above strategies is expected to help in achieving priority action 4 of 
the Hyogo Framework for Action (HFA) i.e. Reduction of underlying disaster risk factors (also in the built environment).

According to Kahn (2005) and Kellenberg and Mobarak (2008), increasing investments in disaster risk reduction have led to a noticeable reduction in human casualties from disasters but economic loss. Although, economic loss from disasters are caused by several factors, among these are damages to properties, business disruption, and damages to stocks, the value of built environment damages and its consequential impacts are significant (Haigh 2010; UNDP 2013). Therefore, a review of investment in disaster resilience in the built environment becomes essential. Obviously, government cannot make all needed investments but the private sector under-invests generally as a result of information asymmetry, myopic behaviour, excessive short term targets and cost cutting among others (Neumayer et al. 2014; Warhurst 2006). The above mentioned factors were referred to as "market failures" by Neumayer et al. (2014). The study went ahead to suggest the use of incentives that are based on disaster propensity to overcome the failures.

Since the attainment of resilience attracts additional initial cost (Warhurst 2006; Neumayer et al. 2014), a more systematic approach is perhaps needed to achieve a desirable level of investment in disaster resilience. Although, disaster resilience as a theme has gained a significant level of popularity and has attracted an appreciable level of debate among academic and practitioners across professions, no one has actually carried out a critical investigation and analysis into issues relating to finance and investment in disaster resilience in the built environment. This paper intends to fill this gap by highlighting and discussing issues relating to investment in disaster resilience in the built environment, it identifies methodological problems as well as research and practice gaps and potential solutions.

The objectives of this paper are to describe and compare the options available for financing disaster risks for resilience in the built environment; review sample investment and financing efforts made towards achieving disaster resilience in the built environment across sectors. The paper also discussed some strategic approaches through which stakeholders relate and invest in achieving disaster resilience; reviewed the barriers, drivers, benefits and incentives for investing in disaster resilience in the built environment; and identified key points that can benefit research and practice.

\section{RESEARCH METHOD}

This paper is based on relevant literature materials gathered from leading depositories of disaster resilience publications. Technical reports on investment- in disaster resilience related activities were gathered from PreventionWeb - a United Nations International Strategy for Disaster Reduction (UNISDR) repository, launched in 2007. The repository was established to serve as a storage and information outlet for the disaster risk reduction (DRR) community. PreventionWeb allows all interested organisations and individuals to publish disaster resilience related documents and events, it also has capacity to search for documents in hundreds of other DRR websites. PreventionWeb can be referred to as a good pool of resources relevant to this work. Other reports were obtained mainly from World Bank and Asian Development Bank websites. Journal articles were basically collected from leading journal databases among other sources. Among the databases are: Taylor and Francis, Emerald, Science Direct, and Elsevier Journals. Preference was given to publications between year 2005 and 2014, this is because the most recent largely accepted framework for disaster management - Hyogo Framework for Action - took effect in 2005 (now succeeded by Sendai framework 2015). It is believed that the framework has provided a structured approach to all disaster management activities including finance investments. Keywords were used for searches done in the aforementioned depositories and materials generated were refined, sorted and evaluated so as to have only the materials suitable for the focus of this study.

\section{DISASTER RESILIENCE}

Among the several definitions of resilience, the UNISDR (2009) definition of resilience in the context of disasters as "the ability of a system, community or society exposed to hazards to resist, absorb, accommodate and recover from the effects of a hazard in a timely and efficient manner, including through the preservation and restoration of its essential basic structures and functions" appears to be among the most popular and perhaps the most acceptable in recent disaster literatures. However, Tainter and Taylor (2014) described disaster resilience as the ability to recover from a setback. Invariably, resilient societies must have appropriate problem-solving capacity to adjust to setbacks without distortion. As earlier mentioned, 
the attempt to describe resilience has been greeted with several submissions from authors, this, coupled with the interdisciplinary attribute of resilience is nearly bringing confusion (Twigg 2009). However, except for the emergence of the principle of "bouncing forward" in the disaster resilience community (Manyena et al. 2011), there is a high level of similarity in the practical implication of almost all earlier definitions. The "bounce forward" paradigm still require further development as there is a cloud of ambiguity on the real meaning and boundaries of the bouncing forward of a society after a disaster.

\section{BUILT ENVIRONMENT (PROPERTIES) AND DEVELOPMENTS}

Generally, more investments in the built environment and infrastructure are expected over the coming years. Global Construction Perspectives and Oxford Economics (2011) estimated project investments in urban areas to rise by $67 \%$ - i.e. from about US $\$ 7.2$ trillion in 2011 to around US $\$ 12$ trillion by 2020 . By the year 2020 , about US $\$ 97.7$ trillion is expected to be spent on construction globally thereby bringing the contribution of construction to world GDP to about $13.2 \%$. However, as significant as the projections appear to be because of its tendency in expanding existing business and creating new ones, the challenge it stands to pose to disaster risk reduction and disaster resilience of the society should remain an issue of utmost concern. This is because much of this development is expected to take place in disaster prone or vulnerable areas and some countries with relatively weak disaster risk management system; the developments will also increase the concentration of wealth in some areas. It should be noted that the magnitude of loss from disasters is a function of the wealth of the affected area (Bouwer et al. 2007; Neumayer, Barthel 2011; Pielke et al. 2008).

According to IIHS (2012) much of the developments in Delhi, India occurred in hazard prone areas despite the knowledge and awareness of the risks of flood and earthquake. Also, in the United Kingdom, despite the existence of policy frameworks, regulations and monitoring agencies, the number of properties developed on flood plains are still increasing (Committee on Climate Change 2012). In November 2012, many parts of the country were affected by flooding; this left about 1100 homes damaged or destroyed. The flooding was estimated to cost insurers $£ 500$ million and esti- mated to increase annual insured loss in the UK for 2012 to about $£ 1$ billion (about USD1.60 billion). The 2012 estimate ranks among the highest in terms of claims processed in recent times (AON Benfield 2012). Also, in Slovenia and Croatia, AON Benfield (2012) reported that excessive rain led to flooding along Drava and Sava rivers and this resulted to the damage of more than 4,500 homes and other buildings. This amounted to an economic loss of around EUR209 million (US\$265 million). The UK event eventually triggered some reforms in the management of flood risk though, much can still be done. If adequate consideration is given to the need for disaster resilient infrastructure and properties, and the needed resources are sourced and invested, the expected future development in the built environment will be a great opportunity for achieving a disaster resilient future. Presented in the next section are the options available for financing disaster risk and enhancing resilience. The options presented and the associated brief descriptions provides for quick comparison.

\section{FINANCING DISASTER RISK AND INVESTING IN DISASTER RESILIENCE}

Beyond the potential use of the information provided in this section, a discussion on finance and investment in disaster resilience will be technically deficient if no reference is made to the probable sources of investment. Priority Action Four (4) of the HFA is targeted at reducing underlying risks of disaster. One major task under the priority action 4 is to ensure the existence of appropriate risk management systems. It should be recalled that the ability of the built environment to withstand, absorb and recover from the impact of disaster goes a long way in speeding up the recovery of an entire system from eventualities. Therefore, reducing the underlying disaster risk factor in the built environment will go a long way in ensuring the resilience of societies to disasters. Obviously, only little can be done in reducing underlying risks if suitable risk finance mechanisms or investment sources are not available. Since it is practically impossible to completely insulate the built environment, community, and a nation from natural disasters, pre-disaster investments made in the right direction coupled with transfer of risks to the party that can best manage them as well as a reasonable level of post-disaster response capacity is germane. A detailed comparison of the major disaster risk financing mechanisms is summarized in Supplementary Appendix A (available in the online ver- 
sion only). Each of the mechanisms is identified as a prevention funding mechanism (i.e. pre-disaster investment financing), loss financing mechanism (i.e. post disaster loss management mechanism), loss finance transfer or combination of prevention and loss financing.

The risk financing options presented in Supplementary Appendix A (available in the online version only) have their respective merits and demerits, from the categories presented; prevention funding mechanisms allow for reduction of risks before catastrophes but on most occasions, it implies that the party that is exposed to the risk bears the risk eventually. Also, the adequacy of investments needed is a function of the accuracy attained in estimating disaster risk; this brings the thought of whether the investments will actually prevent, mitigate, or fail to make any impact in the event of a disaster. Examples of prevention funding mechanisms are prevention and mitigation fund, mitigation loans, prevention loans. Loss financing mechanisms are available for financing losses after a disaster, by implication this financing mechanism are response options. There have been arguments on the logicality and appropriateness of response to disasters rather that prevention and mitigation. Examples of loss financing mechanisms are external borrowing, loan diversion, calamity funds, and state sponsored loss sharing programmes. The third category referred to loss financing transfer provides the opportunity of transfer of losses resulting from disasters to a third party; examples are insurance and re-insurance, and insurance for disaster reserves.

The issue of disaster risk financing and investment in resilience concerns both developing and developed nations since they are both affected by disasters. However, many fundamental issues have to be addressed alongside disaster resilience finance issues in developing countries. Among these issues are lack of innovativeness, policy frameworks that guide developments and ensure that developments are built in ways that reduces vulnerability and not exacerbate them (Mahul, Gurenko 2006). Another issue is the existence of weak disaster risk management system. Mahul and Gurenko (2006) mentioned the low level of penetration of insurance in developing countries, but since a nation like Turkey can increase residential catastrophe insurance penetration from 3 to $17 \%$ in 3 years, barriers to penetration in developing countries can be surmounted. Some of the usual barriers to penetration are over depend- ence on aid assistance, and poor state of domestic insurance markets. Insurance remains one of the most popular disaster risk financing instruments for enhancing resilience, although it has its shortcomings too. A commentary on other risk financing options is presented below.

Micro-insurance is currently a funding option for poorer communities, since it is currently based on informal cooperative systems, a thorough research aimed at bringing a new generation of micro and macro-insurance system seems important. Catastrophic bond (CAT bonds) which is also managed by insurance and re-insurance companies is an option available for both developed and developing nations. But since the insurance market of many developing nations is weak, the ability of CAT bonds to thrive is slim. Reserve fund is another instrument that provides liquidity after a disaster (Miller, Keipi 2005; Freeman et al. 2003) but since a lot of developing nations do not officially possess enough funds to provide basic amenities, it might be difficult to set funds aside in anticipation for disasters. This finance instrument is currently more useful for wealthier nations, it should be noted that the funds set aside also has a cost (i.e. returns from potential uses of the fund set aside).

External borrowing, loan diversion, emergency loan, reconstruction loans, mitigation loans, prevention loans, reformulation of existing loans are all loans with consequential commitments. Such loans are usually arranged by governments for citizens. It is useful in both developed and developing nations, though developing nations depend more on such loans. Formal and Informal Risk Coping through Self-Financing, Transfers of Government Budget/budget reallocation, Tax increase and tax exemption reduction, and Government/State sponsored loss sharing and mitigation grants are used more in developed countries. Their use in developing countries is limited perhaps due to low level of awareness, rigidity of governance system which hardly brings about tax change, as well as the usually acclaimed low level of wealth in developing nation. Above all, many of these finance mechanisms have a long history of existence, it is time to develop new generation disaster finance systems that is country specific, and focuses more on mitigation and prevention rather than loss finance and even loss finance transfer. Presented in the next section are samples of investments made across selected sectors using some of the funding mechanisms discussed above. 


\section{INVESTMENT IN DISASTER RESILIENCE IN THE BUILT ENVIRONMENT ACROSS SECTORS}

Before the 1995 earthquake, Kobe port was among the busiest ports in the world. After the earthquake, the port which used to rank $6^{\text {th }}$ in the world fell to $17^{\text {th }}$ place in 1997 after two years of reconstruction (Chang 2000); in year 2000, it became $23^{\text {rd }}$ and by 2013 it fell to $52^{\text {nd }}$ place (Containerisation International 2013). The business disruption experienced by the port as a result of the earthquake remains the major reason for the sharp slip in performance. Business did not return to the level it used to be despite several efforts and incentives made available to port users. Among the efforts are reduction of harbour dues, land rental fees, and 24-hour operation. This remains a valid example of the implication of damage to business premises and/or built environment by disasters on a typical system. The Kobe loss and delay in recovery could have been significantly reduced if necessary investments with respect to infrastructure strengthening and business continuity practices have been made.

Neumayer et al. (2014) stated that two main strategies are available for the reduction of cost or impact of disasters. One option is to avoid settling or operating in high risk areas, the other option is to build properties that have little probability (if any) of being damaged by hazards. However, on most occasions, areas with high risk of disaster have economic advantages such as low labour costs, access to export markets, access to materials among others. Also, putting up disaster resilient structures attract additional costs. Therefore, the options attract costs, the former is opportunity cost and the latter is in form of direct investment. Understandably, investments in disaster resilience require adequate evidence of superiority of benefit to cost. In this regard, joint investments can enhance the business case of investments. A detailed look at examples of investments in built environment resilience and some related issues in selected sectors are presented below.

\subsection{Education}

The term "hardening" is another term used for resilience building or the act of increasing the ability of infrastructure to withstand stress from hazards. In 1996, a middle school in Wisconsin, one of the 180 structures damaged by a tornado that struck the community was later "hardened". After the tornado incident, the need for resilience of infrastructure was clearer and this led to the school being rebuilt to withstand $150-\mathrm{mph}$ wind as against the 88-mph stipulated in the public building code for Wisconsin. This was however achieved at a significantly higher cost, the internal walls were hardened and the roof was bolted to wall supports. The investment made in strengthening the school amounted to $\$ 207,260$; the larger part of the expended cost was obtained from mitigation fund (WDEM 2001). This gave the school the ability to endure twice the wind that most others are built to endure thereby giving a greater sense of safety and security. The school can also serve as a community shelter in the event of another tornado.

\subsection{Health}

Hospitals are critical to post disaster relief and recovery, damages to hospital structures, hospital equipment and surrounding facilities can lead to a big setback to the relief and recovery process. Geroy and Pesigan (2011) concluded that there is a gap in hospital infrastructure, emergency equipment and capacity in the face of disaster emergencies. The study emphasized the need to enhance the resilience of health facilities. Also, in a study conducted by Rautela et al. (2011) on seismic vulnerability of health infrastructure in India, it was found that $80 \%$ of the health facilities in one of the study areas is very likely to be non-functional in a post-earthquake situation as a result of damages. The study suggested improvement health facility's post disaster capacity through investment in retrofitting. Towards enhancing facilities' capacity, some organisations e.g. Pan American Health Organization (PAHO) developed a series of guidelines for assessing the probable response of hospital structure, equipment, and surrounding facilities to disasters (Rossetto 2007). Hurricane Ivan that struck Grenada in 2004 resulted to a major loss for schools and hospitals. Only two of the about 75 primary and secondary schools experienced minimal damage; the largest hospital on the Island experienced about $70 \%$ damage. The second largest hospital was also physically damaged and was not suitable for use; worthy of note is that the two schools that were left standing after the disaster were retrofitted before the disaster through a World Bank initiative (Rossetto 2007). On a contrary case, Kobe general hospital in Kobe, Japan survived the 1995 earthquake; the hospital was still barely functional as a result of the collapse of the bridge linking it with the mainland. Beyond hardening or strengthening of infrastruc- 
ture, adequately considering the possible impact of hazards in the design and siting of key facilities and the infrastructure serving them can largely improve their disaster resilience and post-disaster functionality.

\subsection{Tourism/business sector}

The resilience of the supporting facilities of a business has a lot to do with the resilience of the business and of course a nation at large. Tourism is one of the major sectors in a number of economies. On most occasions, tourist attractions or destinations are located at vulnerable sites. This is understandable because some of these locations are either pleasant to sight or possess facilities that are very important to tourism service delivery. In order to ensure a suitable level of resilience, UNISDR and Global initiative for Disaster Risk Management is about to commence a hotel disaster resilience level certification programme (Edo et al. 2014). This is to achieve a reduction in risk to premises, business risk, sustain service provision as well as provide safety guarantee to all stakeholders. UNISDR (2013) reported that Orion, a New Zealand Company invested US\$ 6 million on seismic protection; as a result, the investment saved the company up to US\$ 65 million. This example among others is a good reference for other businesses.

\subsection{Housing}

In the United Kingdom, as time went by, the need for households and individuals to protect their properties against flooding became more important (Pitt 2008). Eventually, organisation and household led flood risk management gained more prominence as opposed to the traditional state centred approach (Johnson, Priest 2008). In order to encourage investment, the Department for Environment, Food and Rural Affairs (DEFRA) in England introduced a $£ 5.5$ million grant scheme called Property Level Flood Protection Grant Scheme in December 2008. Under this scheme, local councils were expected to apply for funding and thereafter subsidise the cost of resistance and resilience installations for interested property owners (DEFRA 2009). The scheme ended in 2011 , but an additional sum of $£ 3.4 \mathrm{~m}$ was allocated by the government for Property level Flood Protection in 2011-2012. A promise of future support to the scheme was made under the succeeding Flood and Coastal Resilience Partnership Funding (DEFRA 2012). The Flood and Coastal Resilience Partnership Funding scheme is meant to encourage investment in flood risk management measures by communities. It provides funding for flood and coastal defence projects as well as property level protection assistance that are to be executed in conjunction with communities. It is part of government's strategy for disaster prevention and mitigation and also part of funding strategy for building property resilience, since total prevention of flood events is perhaps practically impossible. The UK Government is also investing in review and implementation of revised building regulations and surface water drainage, sewage system and back garden management among others (DEFRA 2012).

\subsection{Power}

A level of risk can be managed via proactive use of prevention, mitigation and existing disaster resilience measures. For example, International Development Bank financed the strengthening of Sabaneta Dam in Dominican Republic in 1998; this eventually mitigated the risk of flood to the extent that when Hurricane George struck in the same year, there was no significant damage to the power plants. Also, no potential downstream damage was recorded (Keipi, Tyson 2002). Resulting from previous experiences with flood, Yorkshire Electricity Distribution Ltd. (YEDL) invested in making its infrastructure more resistant to flood risks. YEDL built defences at its high risk electricity sub-stations after the year 2000 flood events and this is believed to have helped the company to reduce the impact of flooding on its assets (Pitt 2008). In the year 2007, there was a massive flooding in North East England, the investment made by YEDL paidoff, as the Blackburn Meadows electricity substation protected by flood defences was not significantly affected. The sewage treatment plant that shares the same site with the power sub-station was with no form of protection from flooding; consequently the treatment plant was significantly damaged and cost $£ 17$ million to repair.

From the examples above, it is clear that stakeholders in the disaster resilience theme have been making frantic efforts to curtail the impact of disasters on the society. Noticeably, changes in disaster related policies worldwide are also affecting the area of finance and investment in disaster risk reduction and disaster resilience. For instance, a major shift was observed when DEFRA (2011) recommended that property owners should take the responsibility of adapting their properties to flood since the total prevention of flooding is seemingly impossible. This brings to prominence the need to 
invest in enhancing coping and adaptive capacities for operations as well as resistance and resilience ability of properties to disasters. Also, the recommendation DEFRA (2011) technically emphasise the shift in the responsibility for funding of building resilience from the government to individuals, businesses and the private sector at large. It is ideal to say that this is connected with recent cuts in government spending in the United Kingdom (Crawford, Phillips 2012; Committee on Climate Change Adaptation 2015) and the identified capacity of the private sector worldwide in building resilience (ADPC 2013).

The change in policy raises the question of whether property owners have the resources required to achieve this. If government interventions in developed countries (DEFRA 2015) can help in achieving this, it is definitely going to be a problem in poorer or developing nations. These nations are largely dependent on foreign assistance and guidance in terms of capacity building and infrastructure finance, and they have relatively weak disaster risk management systems. Some strategic approaches through which stakeholders relate and invest in achieving disaster resilience are discussed in sections 7, 8, and 9 below. The approaches have been adopted in many sectors and seem suitable for use in many others.

\section{DISASTER RESILIENCE IN THE BUILT ENVIRONMENT AND PUBLIC PRIVATE PARTNERSHIP}

Public-private partnership (PPP) can be described as a contractual agreement between a public sector organization and a private sector entity, this contractual agreement allows for an improved private sector involvement in the delivery of public infrastructure projects (Deloitte 2006). Just several other technical terms, public-private partnership has been given various definitions by several authors, sometimes based on respective author's context of interest. After considering a number of definitions, Leiringer (2006) described public-private partnership as "an arrangement between public sector and private sector investors and businesses whereby the private sector on a non-recourse or limited recourse financial basis provides a service under a concession for a defined period that would otherwise be provided by the public sector." The content of the partnership is practically a function of what the parties to the contract decide to include. It has been argued that the private sector has some qualities and capabilities that are not easily found in government agencies. These qualities can also be exploited in the context of disaster resilience in the built environment through public and private collaboration. Beyond exploiting the capabilities, the private sector occupies a significant position and stands a good chance in influencing disaster risk accumulation. Worthy of note is the fact that the private sector owns much of a country's infrastructure. For instance, $85 \%$ of the critical infrastructure in the US is privately owned (Miler 2013). Therefore, there is the tendency of high loss on the part of the private sector in the event of disaster. Private sector's readiness to build-in resilience in partnership with the government with respect to the infrastructure it provides is a great opportunity to explore. Opportunities to enhance disaster resilience through public-private partnership seem under-utilized because building resilience is largely perceived to be a public sector responsibility (PwC 2013). Zhang and Kumaraswamy (2013) explored PPP as an innovative post-disaster reconstruction approach using a china case study, the study thereafter emphasized the importance of engaging 'people' in post-disaster reconstruction. Also, Ingirige et al. (2015) made a strong case for the full use of public private partnership (PPP) in the delivery of selected infrastructure projects during post-disaster reconstruction and recovery. The study however pointed out some of the merits and demerits noticeable from the application of PPP in the delivery of conventional public infrastructure. It was also clearly stated that PPP or $3 \mathrm{P}$ might not be suitable for all disaster risk management/resilience related projects. Many of the demerits and pitfalls can however be surmounted by adequately embedding 'People' in the $3 \mathrm{P}$ to become $4 \mathrm{P}$ through pre-disaster planning.

A suitable case of how PPPs can help reduce disaster risk and enhance resilience is the case Christ Church Earthquake, New Zealand in September 2010 and February 2011 which led to a loss of about US $\$ 4$ billion and US $\$ 12$ billion. Prior to the event, Christ Church Engineering Lifelines Study (Christchurch Engineering Lifelines Group 1997) conducted a study to address a range of hazards including earthquakes, snow and windstorms, flooding and tsunamis. Engineers and managers from local authorities and utility organisations as well as public and private companies were engaged in the project. After the study was conducted, Christchurch's utility companies led the building of disaster risk management in daily business practices. There were Inter-organisational collaborations facilitated and formalized by Can- 
terbury Lifeline Utilities Group. The investments and efforts paid off after an earthquake struck afterwards, Port of Littleton resumed operations few days after, although a level of damage was recorded on the ports commercial buildings and some other physical facilities. Telecommunications buildings that was reinforced before the event was not affected by the disaster and therefore remained in use, a number of bridges that were retrofitted by the City Council and New Zealand Transport Agency survived the quakes, the US $\$ 6$ million investment in seismic protection by Orion, the local electricity distribution company, reportedly saved the company about US\$65 million in direct losses.

Sadly, housing losses were high as a result of the historic poor land use decisions; a number of residential apartments were developed on lands that are susceptible to earthquake impacts. The public private people partnership (4P) framework presented by Zhang (2012) and Ingirige et al. (2015) will serve as a good foundation for a structured use of $3 \mathrm{P}$ and $4 \mathrm{P}$ in disaster resilience and disaster recovery related projects in the built environment. Testing and further developments is very necessary. Legislative changes will however be needed to enhance the current approaches and to effectively embed the community. Rotimi et al. (2009) discussed the need for legislative changes so as to effectively achieve post-disaster reconstruction. Alongside relevant legislative changes, effective use of knowledge from previous experiences is essential (Kaklauskas et al. 2009). In respect of the need for policy changes, the government of England introduced a central government's funding structure for flood and coastal erosion risk management in 2011. Under a scheme called Flood and Coastal Erosion Resilience Partnership Funding, the central government can now fund an array of valuable projects rather than bear the full cost of few projects (DEFRA 2015). The remaining costs of such projects are provided by local communities and environmental agency while administrative responsibilities are handled as agreed. The power of the local authority to carry out risk management works on regular water courses remains. Although the mode of public private partnership in developed countries may differ a bit between developing countries and developed countries as a result of peculiarities in economy, culture, legal and administrative structure of these nations, the underlining principles of PPP remains across board. The partnership funding scheme in England and the Christchurch's utility companies led interven- tion that engaged public and private companies in New Zealand among others are all varieties of partnership. Presented in the next section are benefits of investing in resilience. All stakeholders in both developing and developed nations can benefit by exploiting any of the opportunities that relate to the benefits discussed below. Developed nations can lead the implementation of some of the PPP initiatives that are applicable in the developing nation context, for example Safaricom/GE and Kenyan government's partnership and Swiss Re arrangement in Ethiopia ( $\mathrm{PwC} 2013)$. A modified version for application in a developed country context can be an agreement that permits private sector companies to provide resilient materials to home builders with defined government support. Another example is an agreement that permits private sector companies to invest in the strengthening or hardening of critical infrastructure in flood prone areas (DEFRA 2009).

\section{DISASTER RESILIENCE IN THE BUILT ENVIRONMENT AND CORPORATE SOCIAL RESPONSIBILITY}

Corporate social responsibility (CSR) is fast becoming one of the factors that contribute to the development of a business (Zhao et al. 2012). Moneva et al. (2007) submitted that strong corporate structure and commitment to social and ethical values can increase productivity and prevent legal issues, it implies that such commitments will enhance the financial performance of such companies. ISO (2010) defined corporate social responsibility as the "responsibility of an organisation for the impact of its decisions and activities on society and the environment, through transparent and ethical behaviour". Businesses participate beyond the protection of their own human and economic assets at the response phase of a disaster; this is usually done as part of their CSR activities. It is indeed important for organisations to expand their CSR activities beyond response stage, currently, much of their activities are about cash donations, debris clearing, use of employees as volunteer, lending of machinery/equipment etc. The involvement of organisations in disaster risk reduction is important as the world is moving towards risk prevention and mitigation rather than response and relief. The paradigm of CSR in disaster resilience should also change as the approach of the world to disaster risk changes.

The Rana Plaza building collapse in Savar, near Dhaka, Bangladesh reportedly has about 1,100 
victims, this has led to a shift in the traditional company resilience thinking pattern to worldwide value chain order. The incident emphasized the need for attention on supply chain, especially when developing countries are involved. This is because many of these countries do not have strong disaster management systems and when unpleasant events strike, the whole supply chain will be affected. Blowfield (2000) while discussing ethical sourcing emphasized the need for a comprehensive set of codes that brings all stakeholders together to address issues that affects the entire value chain. Similarly, Preuss (2009) examined codes on CSR in supply chain through the lens of sustainability. It is time to place better attention to the link between disaster resilience and codes on CSR in supply chain. For example, after the incident in Bangladesh, Primark, a garment sale company, alongside other organisations undertook building safety survey for factories from which it source garments and became a signatory to the accord on fire and building safety. It also revised its sourcing policy. Organisations should learn to bear the responsibility of applying best practices in their supply chain through the principle of CSR. Organisations can audit disaster resilience ability of their network of stakeholders for satisfactory performance as part of their CSR (Wieland, Handfield 2013).

\section{DISASTER RESILIENCE IN THE BUILT ENVIRONMENT AND BUSINESS CONTINUITY MANAGEMENT}

Providing protection for all assets might not be practical or economical. Even if all necessary efforts are made to achieve this, preparations or efforts can get overwhelmed. This therefore underlines the need for Business Continuity Management (BCM). The British Standards Institution defines BCM as: "A holistic management process that identifies potential threats to an organisation and the impacts to business operations that those threats, if realised, might cause, and which provides a framework for building organisational resilience with the capability for an effective response that safeguards the interests of its key stakeholders, reputation, brand and value-creating activities" (British Standard Institutions 2007).

Tierney (2007) among other authors have clearly discussed the existence of direct and indirect impacts of disasters on businesses. Ideally, organisations should make all necessary efforts to avoid significant losses from disasters. However, several barriers as will be discussed in the later part of this paper are militating against wide and effective use of strategies available for resisting, withstanding and absorbing stress from hazards. From the definition of Business Continuity Management (BCM) given above, BCM practically goes beyond the act of ensuring the resilience of the immediate premises of an organisation. It extends to the attainment of the resilience of an organisation's process, supply chain, customer preservation, and public image among others. However, since an organisation's processes depend on the functionality of infrastructure and business premises, the resilience of infrastructure is therefore a strong influencer of business continuity and loss reduction. Then, the importance of the resilience of the built environment in the overall resilience agenda cannot be overemphasized (UNDP 2013).

\section{BENEFITS OF INVESTING IN DISASTER RESILIENCE IN THE BUILT ENVIRONMENT}

\subsection{Market opening, market expansion, market stabilization and other benefits}

Economic loss from disasters will continue to increase unless drastic control measures are taken (Bouwer et al. 2007; Ki-Moon 2013; Pielke et al. 2008). Beyond the tendency of reducing economic loss from disasters through improved investment in built environment disaster resilience, some other benefits abound. Market opening, expansion and stabilization potentials of investing in resilience refers to the tendency of a new product/service being created, or existing ones expanded or existing ones made established. This will be achieved as a result of innovations towards enhancing resilience of enterprises.

The opportunity to develop and distribute new resilience enhancing products and services is a worthy driver of investment in resilience. This opportunity brings the benefit of a competitive market advantage alongside the creation of a new income stream for a typical organisation. It is also a chance to diversify risk portfolio. The market opening and expansion ability of investing in disaster resilience was explored by Swiss Re in Ethiopia. PwC (2013) reported an arrangement made by Swiss Re (and partners) in Ethiopia whereby farmers pay their insurance premium by working on community-identified projects to build resilience. In the illustration above, the farmers were indirectly contributing towards building resilience, enhancing their own resilience while Swiss Re (and 
partners) expanded their market and were also investing in resilience. Being able to introduce new products and services to the market or expanding existing products and services also increases a company's revenue and market share. It also has the ability of enlarging and extending a company's relevance, success as well as competitive advantage. Cost savings can be referred to as one of the drivers for investing in resilience; the actual benefits of all cost saving efforts are some or all of the following: reduced operational cost, security of profit, reduced cost of raw materials, and enhanced resource efficiency ( $\mathrm{PwC}$ 2013). The image of an organisation speaks a lot about the potential success of such organisation. Therefore, the need to build brand value and reputation cannot be overemphasized. An organisations brand value and image can also be boosted through investment in resilient activities. Beyond the benefit of a pleasant social image, it is an opportunity to display market leadership and prowess (UNISDR, GFDRR 2012; PwC 2013). This will increase the confidence of all stakeholders especially that of consumers and investors. In addition to the aforementioned benefits, UNISDR and GFDRR (2012) stated that investing in disaster risk reduction and resilience guarantees the safety of lives and properties, it helps to reduce the diversion of resources to response and recovery, increases investors' assurance, creates business opportunities, secures economic growth and makes employment safer and also help cities that have invested in resilience and even organisations to attract investment. Other benefits are reduced failure probabilities and/or time to recovery, and community wellness.

\section{BARRIERS AND DRIVERS FOR INVESTING IN DISASTER RESILIENCE IN THE BUILT ENVIRONMENT}

\subsection{Barriers to investment in disaster resilience}

While discussing issues relating to the use of resistance and resilience measures, (Bichard, Kazmierczak 2012) mentioned poor attitude and wrong perception of property owners as one of the barriers to investment in flood resistance and resilience measures. The study stated that many people are aware of living in risk areas but they seemingly underestimate the risk. Many property owners simply do not see the reason to spend on flood proofing their properties. In a similar vein, Kenna (2008) decried the availability of just lit- tle incentive for installing resilient measures. It opined that risk-based insurance system is a viable incentive for enhancing investment in property resilience. Although, the use of incentives remain a viable means of encouraging the adoption of resilience, efforts toward the realization of the full cost of direct and indirect impacts of disaster remains germane. This is because the underestimation of the impacts of disaster by businesses limits the adoption of property level resilience measures, since a convincing picture of benefits to cost of investments in resilience cannot be seen (Wedawatta et al. 2014). While discussing barriers to investment and actions in enhancing disaster resilience, $(\mathrm{PwC}$ 2013) mentioned the difficulty in engaging businesses on issues that go beyond their operating boundary. It is believed that a strong business case with adequate awareness and interest building efforts is the potential solution to the identified barrier.

A lot of businesses are driven mainly by profit and are unwilling to venture beyond their traditional scope of operation. Investment in resilience should however be seen as a way of making all investments attractive and secured (United Nations 2013). Although, some organisations have accepted the need to build resilience, limited in-house capacity and leadership to assess risks, understand risks and thereafter implement necessary actions remain a challenge (PwC 2013). The broad list of barriers provided by $\mathrm{PwC}$ (2013) are risk management capability and maturity - internal buy in, awareness, facilities; technical barriers - workforce capacity, technology, knowledge sharing, and access to early stage capital; Financial - technology risk, incentives, technology cost gaps; local enabling environment - policy, infrastructure, political and governance risks. In addition, Pitt (2008) canvassed for the revision of regulations so as to make all new and or refurbished buildings in high risk areas resistant or resilient. This simply implies that the lack of regulations that are meant to ensure the provision of resilience is a barrier.

\subsection{Drivers for investment in disaster resilience}

There are a number of drivers for investment in disaster resilience as seen in literature. $\mathrm{PwC}$ (2013) mentioned the opportunity to develop and distribute new products and services as one of the drivers. Expanding a company's range of products and services in the market does not only increase a company's revenue and stake in the market but 
also gives the company a strong competitive advantage. The products and services are basically to be used by others to enhance their own resilience. Also, the opportunity to expand markets for existing products and services is a viable driver for investing in resilience ( $\mathrm{PwC}$ 2013). For example, Safaricom/GE is a partnership that supports the expansion of low carbon telecommunication infrastructure in Kenya; this is done through the use of solar-powered base station units. This project ensures continued communication since the base station units are resilient to power cut. Cost savings is another driver for investing in resilience (UNISDR, GFDRR 2012). Ensuring the continual availability of raw materials from resilient suppliers will definitely lead to cost saving for a manufacturing company, non-resilience of supply chain will lead to increased raw material operational cost. Reputation and brand value is another driver for investment ( $\mathrm{PwC}$ 2013), For instance, Siemens Company developed a low-cost portable water purification system that does not require chemicals and does not depend on electricity. It can be used to meet the post disaster needs of communities. This development has boosted the reputation of the company not just with in respect of other business they are into but with regard to their capability in offering technologies that can help overcome post-disaster challenges. In the writings of Edo et al. (2014) companies engage or invest in resilience activities for three main reasons: (1) Legal compliance (2) Social responsibility (3) Economic benefits, the three reasons but legal compliance is not far from the submissions of $\mathrm{PwC}$ (2013) as regards the drivers of investment.

It should be noted that social responsibility and economic benefit can be satisfied through any of the ways earlier discussed. The decision to invest in disaster resilience depends on the size, sector, current capability level of the party involved and the jurisdiction in which investment is needed. Some of the incentives that are already in use or recommended for use by NRMCA (2013) are premium incentives or income tax credits for building to code, FORTIFIED standards or using robust materials. Others are: making incentives available to organisations rendering key services during disaster events, expansion of the coverage of sustainability certification to include resiliency and running a lesser mortgage rate for building to disaster resilience standards. Even if incentives are not readily available, potential benefits should be sufficient to convince governments or organisation to invest in resilience. In fact, business organi- sations that decide to invest in risk management stands the chance of financially outperforming their peers (UNDP 2013).

\section{SUMMARY AND CONCLUSIONS}

The summary of some gaps and challenges identified from the case studies of investments and the review carried out on issues associated with investment in disaster resilience in the built environment are hereby presented.

The existence of weak institutions and nonimplementation of good developmental policies hampers resilience and accentuates the problem of financing and investment in resilience in developing nations. Also, after examining the case applications presented in Supplementary Appendix A (available in the online version only) and other parts of this paper, it is rational to conclude that both developed and developing nations are striving to reduce the cost of disaster and improve investment and finance for resilience. Developed nations are leading the drive, not because they are financially buoyant, but because there are stronger institutions and drive to maintain global influence. These nations develop strategies and concepts, draft policies to address challenges, help developing nations, and technically expand markets. Literature revealed that many of the existing financing options and approaches of investment emanated from developed countries. Also, international non-governmental organisations and governments of developed countries lead the drive for disaster risk finance for resilience while the private sector largely invest in resilience through self and supply chain continuity management, aids, corporate social responsibility and some forms of partnership.

An in-depth research is needed to establish funding gaps across nations and this should lead to the development of new generation disaster funding systems. With regards to funding sources, analysis by Hochrainer et al. (2013) shows that government as well as other stakeholders depend so much on traditional sources of financing losses from frequently occurring small to medium-sized disasters. The study expressed serious concerns about the sustainability of the approach and called for increased investment in mitigation, either from public or private sources. Developments on existing risk financing systems earlier discussed in this paper (see Supplementary Appendix A - available in the online version only) to reflect present day demands will be a right move in a right direction. 
Also, many of the documented investments were made after disaster struck once or after it struck at a nearby location. This is obviously inadequate, it is ideal to assess risks independently and make all efforts to mitigate the ensuing risks. It is always more economical and logical to mitigate than to spend on post disaster reconstruction. Ultimately, it is a business decision made on an evaluation of business risks. Also, cost-benefit analysis of investments in built environment resilience is still unclear. Although, there are case studies showing how benefits of investment in resilience outweighs its cost, no definite figures for cost-benefit ratio were available for most of other investments. It was found in literature that it is currently difficult to measure the actual costs and benefits of disasters accurately; this has been affecting the computation of a convincing business case for investment in resilience on most occasions.

Additionally, Built Environment resilience to disasters is not totally a function of the volume of investment made on hardening or strengthening properties, but also the extent of consideration given to design and siting of facilities as well as the level of interconnectivity of facilities. Adequate consideration for resilience while designing and siting properties coupled with huge investment in hardening/strengthening will perhaps yield a better result. In a similar vein, investments in disaster resilience in the built environment are not currently being documented like investments made in humanitarian and relief services. Reports on investments in relief are readily available but records and clear figures on disaster resilience investment in the built environment are scant. Although, information on general expenditures on disaster risk reduction and post-disaster recovery exists, better analysis of the return on investment in resilience in the built environment can only be carried out if adequate information is available.

From the analysis of Kellett and Sparks (2012) a high level disproportion of investment in the reduction of disaster risks and enhancement of disaster resilience can be observed. Between year 2000 and year 2009, investment in disaster risk reduction and resilience enhancement amounts to only $1 \%$ of the entire official development assistance (ODA) to forty countries. Humanitarian assistance has been given so much priority over so many other possible focuses; even though, it is currently being regarded as a disincentive to investment in disaster resilience by some stakeholders. For instance, the impact of a disaster on the supply chains of an affected business is multi-faceted but it is hitherto not adequately researched, especially, with adequate reference to the influence of premises damage and associated issues.

A growing shift in the approach to disaster risk reduction and enhancement of disaster resilience was observed. This is with respect to the utilization of the principles of corporate social responsibility, business continuity management and public private partnerships even in the built environment. But, since the application of these concepts in disaster resilience is still emerging, much is left to be done in terms of technical structure of the patterns of interaction and best practices among stakeholders. The summary of key issues identified for research and practice are as follows:

\section{Methodological issues}

1. Fundamental issues relating to institution, governance and policies must be at the centre of all disaster resilience finance and investment discussions especially in developing countries. The existence of weak institutions and non-implementation of good developmental policies can frustrate disaster risk finance efforts, accentuate low level of wealth and jeopardise resilience for more years.

2. Developed and developing nations are striving to enhance investment and reduce disaster cost but developed nations are ahead because of stronger institutions and global influence not really wealth.

3. Governments and stakeholders largely depend on traditional sources of finance. Quicker progress on the development of country and even business specific mechanisms is necessary.

4. Many of the documented investments were made after disasters struck once or at a nearby location.

5. Cost benefit analysis of investment in resilience in the built environment remains unclear; no clear figures are available for majority of investments.

6. Adequate consideration for design and siting of properties alongside hardening is germane for future developments.

7. There are reports of insufficient support for DRR and resilience. Humanitarian assistance has been receiving better attention.

8. There is a growing call and attention for the financing of resilience through corporate social responsibility (CSR), public private partnership (PPP), and business continuity management (BCM) decisions. Standardization of these strategies in the disaster theme will be ideal. 


\section{Practice and research gaps}

1. In-depth research is needed to establish funding gaps across nations and this should lead to the development of country/region specific new generation funding instruments. This step among others can redirect the perception of some nations on how best to manage funding for building resilience.

2 . Investments in disaster resilience in the built environment are not clearly documented unlike investments on humanitarian interventions. There is need for clear documentation.

3 . There is need for the preparation of a better structure of relationship and outline of best practices for CSR, BCM and PPP in reducing disaster risk for resilience in the built environment.

Issues relating to investments in disaster resilience in the built environment have been discussed in this paper; this led to the identification of gaps and other issues that require attention. Major investment sources, usually referred to as major disaster risk financing mechanisms were identified and compared. Some probable sectors of investment and samples of efforts or expenditures on resilience in the built environment were discussed. Also, current practice paradigms in the principle of business continuity management, corporate social responsibility and public private partnership were also highlighted. Other associated issues - barriers, drivers and benefits of investing in resilience were also described. It can be concluded that efforts are being made to achieve disaster resilience in the built environment but more efforts and clearer documentation of efforts is indeed important. Learning from experiences of the business community in their disaster resilience related investment decisions can help other businesses, the broader community and, of course, all stakeholders. This paper has set the agenda for a grave need for pursuance of research in investment in disaster resilience in the built environment. It has identified the need to build a body of literature in the area of investment in disaster resilience in the built environment. The methodological issues as well as practice and research gaps identified by this paper among other issues discussed are recommended for attention and immediate research. This is needed for the advancement of built environment resilience through efficient finance and investment.

\section{REFERENCES}

ADPC. 2013. Private sector engagement in disaster risk reduction. Bangkok: Asian Disaster Preparedness Center.

AON Benfield. 2012. Impact forecasting: November 2012 Global Catastrophe Recap [online]. Available at: http://thoughtleadership.aonbenfield.com/Documents/201212_if_monthly_cat_recap_november.pdf [accessed 27 January 2014]

Asgary, A.; Anjum, M. I.; Azimi, N. 2012. Disaster recovery and business continuity after the 2010 flood in Pakistan: case of small businesses, International Journal of Disaster Risk Reduction 2: 46-56. http:// dx.doi.org/10.1016/j.ijdrr.2012.08.001

Bichard, E.; Kazmierczak, A. 2012. Are homeowners willing to adapt to and mitigate the effects of climate change?, Climatic Change 112: 633-654. http://dx.doi.org/10.1007/s10584-011-0257-8

Blowfield, M. 2000. Ethical sourcing: a contribution to sustainability or a diversion?, Sustainable Development 8: 191-200. http://dx.doi.org/10.1002/10991719(200011)8:4<191::AID-SD146>3.0.CO;2-E

Bouwer, L. M.; Crompton, R. P.; Faust, E.; Höppe, P.; Pielke Jr, R. A. 2007. Confronting disaster losses, Science-New York then Washington 318: 753.

British Standard Institutions. 2007. BS25999-1 British Standards Institution's Code of Practice for Business Continuity Management. London: BSI.

Chang, S. E. 2000. Transportation performance, disaster vulnerability and long-term effets of earthquakes, in Second EuroConference on Global Change and Catastrophe Risk Management, 2000, Laxenburg, Austria.

Committee on Climate Change. 2012. Adaptation subcommittee progress report 2012: climate change. Is the UK preparing for flooding and water scarcity?. London.

Committee on Climate Change Adaptation. 2015. Policy note: flood and coastal erosion risk management spending. London: Committee on Climate Change Adaptation.

Containerisation International. 2013. Top 100 container ports London.

Crawford, R.; Phillips, D. 2012. Local government spending: where is the axe falling?, in Emmerson, C.; Johnson, P.; Miller, H. (Eds.). The IFS green budget. London: Institute for Fiscal Studies.

DEFRA. 2009. Government grant to local authorities for household level flood mitigation. London: DEFRA.

DEFRA. 2011. Understanding the risks, empowering communities, building resilience: the national flood and coastal erosion risk management strategy for England. London: DEFRA.

DEFRA. 2012. The Government's response to Sir Michael Pitt's review of the summer 2007 floods. London: DEFRA.

DEFRA. 2015. Central Government funding for flood and coastal erosion risk management in England. London: DEFRA.

Deloitte. 2006. Closing the infrastructure gap: the role of public-private partnerships. Switzerland: Deloitte. 
Edo, P. J. M.; Morris, D.; Puutio, T. 2014. Engaging Asia-Pacific businesses in disaster risk management, in Abe, M. (Ed.). Inputs to HFA-2 Key Area7. Bangkok: The Asian Disaster Preparedness Center.

Freeman, P. K.; Martin, L. A.; Linnerooth-Bayer, J.; Mechler, R.; Pflug, G.; Warner, K. 2003. National systems for the comprehensive management of disaster risk and financial strategies for natural disaster reconstruction. Washington, DC, Inter-American Development Bank.

Geroy, L. S. A.; Pesigan, A. M. 2011. Disaster risk reduction for health facilities in the Western Pacific Region, International Journal of Disaster Resilience in the Built Environment 2: 268-277. http://dx.doi. org/10.1108/17595901111167132

Global Construction Perspectives and Oxford Economics. 2011. Global construction 2020: a global forecast for the construction industry over the next decade to 2020. London, UK.

Haigh, R. 2010. Discussion paper: developing a resilient built environment: post-disaster reconstruction as a window of opportunity, in International Conference on Sustainable Built Environments (ICSBE-2010). Kandy.

Hochrainer, S.; Timonina, A.; Williges, K.; Pflug, G.; Mechler, R. 2013. Modelling the indirect and fiscal risks from natural disasters using the CatSim model: Background paper prepared for the 2013 Global Assessment Report on Disaster Risk Reduction. Geneva, Switzerland.

IIHS. 2012. The role of private sector in reducing disaster risk in large scale infrastructure and real estate development, case of Delhi: Background paper prepared for the 2013 Global Assessment Report on Disaster Risk Reduction [online]. Available at: http://www. preventionweb.net/gar [accessed 27 January 2014]

Ingirige, B.; Amaratunga, D.; Kumaraswamy, M.; Liyanage, C.; Perwaiz, A.; Towashiraporn, P.; Wedawatta, G. 2015. Private investment in Disaster risk management: Background paper prepared for the 2015 Global Assessment Report on Disaster Risk Reduction. Geneva, Switzerland: UNISDR.

ISO 2010. ISO 26000 - Guidance on social responsibility. Geneva, Switzerland: The International Organization for Standardization.

Johnson, C. L.; Priest, S. J. 2008. Flood risk management in England: a changing landscape of risk responsibility?, International Journal of Water Resources Development 24: 513-525. http://dx.doi. org/10.1080/07900620801923146

Kahn, M. E. 2005. The death toll from natural disasters: the role of income, geography, and institutions, The Review of Economics and Statistics 87: 271-284. http://dx.doi.org/10.1162/0034653053970339

Kaklauskas, A.; Amaratunga, D.; Haigh, R. 2009. Knowledge model for post-disaster management, International Journal of Strategic Property Management 13: 117-128. http://dx.doi.org/10.3846/1648715X.2009.13.117-128

Keipi, K.; Tyson, J. 2002. Planning and financial protection to survive disasters. Washington, DC: InterAmerican Development Bank.
Kellenberg, D. K.; Mobarak, A. M. 2008. Does rising income increase or decrease damage risk from natural disasters?, Journal of Urban Economics 63: 788-802. http://dx.doi.org/10.1016/j.jue.2007.05.003

Kellett, J.; Sparks, D. 2012. Disaster risk reductionspending where it should count. Somerset, UK.

Kenna, S. 2008. Do social housing providers across Yorkshire and the East Midlands have effective flood risk management in place when maintaining and repairing their housing stock?, Journal of Building Appraisal 4: 71-85.

http://dx.doi.org/10.1057/jba.2008.28

Ki-Moon, B. 2013. Disaster-related economic losses out of control [online]. Available at: http://www.un.org/ News/Press/docs/2013/sgsm15027.doc.htm [accessed 27 January 2014]

Lawrence, D. L.; Low, S. M. 1990. The built environment and spatial form, Annual Review of Anthropology 19: 453-505. http://dx.doi.org/10.1146/annurev. an.19.100190.002321

Leiringer, R. 2006. Technological innovation in PPPs: incentives, opportunities and actions, Construction Management and Economics 24: 301-308. http://dx.doi.org/10.1080/01446190500435028

Mahul, O.; Gurenko, E. 2006. The macro financing of natural hazards in developing countries, The Policy Research Working Paper Series. The World Bank.

Manyena, S. B.; O’Brien, G.; O’Keefe, P.; Rose, J. 2011. Disaster resilience: a bounce back or bounce forward ability, Local Environment 16: 417-424. http://dx.doi.org/10.1080/13549839.2011.583049

Miler, D. 2013. Rebuilding for resilience. New York: PwC.

Miller, S.; Keipi, K. 2005. Strategies and financial instruments for disaster risk management in Latin America and the Caribbean. Washington, DC: InterAmerican Development Bank.

Moneva, J. M.; Rivera-Lirio, J. M.; Muñoz-Torres, M. J. 2007. The corporate stakeholder commitment and social and financial performance, Industrial Management \& Data Systems 107: 84-102. http://dx.doi.org/10.1108/02635570710719070

Neumayer, E.; Barthel, F. 2011. Normalizing economic loss from natural disasters: a global analysis, Global Environmental Change 21: 13-24.

Neumayer, E.; Plümper, T.; Barthel, F. 2014. The political economy of natural disaster damage, Global Environmental Change 24: 8-19.

NRMCA. 2013. Adopting disaster resilient construction at the local level, Concrete Joint Sustainability Initiative. Maryland, USA: NRMCA.

Pielke, R.; Gratz, J.; Landsea, C.; Collins, D.; Saunders, M.; Musulin, R. 2008. Normalized hurricane damage in the United States: 1900-2005, Natural Hazards Review 9: 29-42. http://dx.doi.org/10.1061/ (ASCE)1527-6988(2008)9:1(29)

Pitt, M. 2008. The Pitt review - learning lessons from the 2007 floods. London.

Preuss, L. 2009. Ethical sourcing codes of large UKbased corporations: prevalence, content, limitations, Journal of Business Ethics 88: 735-747. http://dx.doi.org/10.1007/s10551-008-9978-7 
PwC. 2013. Stimulating private sector engagement and investment in building disaster resilience and climate change adaptation. UK: PriceWaterhouseCoopers.

Rautela, P.; Joshi, G. C.; Bhaisora, B. 2011. Seismic vulnerability of the health infrastructure in the Himalayan township of Mussoorie, Uttarakhand, India, International Journal of Disaster Resilience in the Built Environment 2: 200-209. http://dx.doi.org/10.1108/17595901111167088

Rossetto, T. 2007. Construction design, building standards and site selection, Guidance note 12 , in Benson, C.; Twigg, J. (Eds.). Tools for mainstreaming disaster risk reduction: guidance notes for development organisations. Geneva: International Federation of Red Cross and Red Crescent Societies / the ProVention Consortium, 141-152.

Rotimi, J. O.; Wilkinson, S.; Zuo, K.; Myburgh, D. 2009. Legislation for effective post-disaster reconstruction, International Journal of Strategic Property Management 13: 143-152. http://dx.doi.org/10.3846/1648715X.2009.13.143-152

Tainter, J. A.; Taylor, T. G. 2014. Complexity, problemsolving, sustainability and resilience, Building Research \& Information 42: 168-181. http://dx.doi.org /10.1080/09613218.2014.850599

Tierney, K. 2007. Businesses and disasters: vulnerability, impacts, and recovery, in Rodríguez, H.; Quarantelli, E. L.; Dynes, R. R. (Eds.). Handbook of disaster research. New York: Springer. http://dx.doi. org/10.1007/978-0-387-32353-4_16

Twigg, J. 2009. Characteristics of a disaster-resilient community (Version 2). UK: Department for International Development.

UNDP. 1994. Disaster mitigation. New York: UNDP.

UNDP. 2013. Small businesses: impact of disasters and building resilience. Analysing the vulnerability of micro, small, and medium enterprises to natural hazards and their capacity to act as drivers of community recovery. Geneva: UNISDR.

UNISDR. 2009. UNISDR terminology on disaster risk reduction. Geneva: UNISDR.

UNISDR. 2013. From shared risk to shared value - the business case for disaster risk reduction, Global Assessment report on disaster risk reduction. Geneva: UNISDR.
UNISDR \& GFDRR. 2012. How to make cities more resilient: a handbook for local government leaders. Geneva: UNISDR.

United Nations. 2013. Private sector must engage in disaster risk reduction to avoid economic losses - UN [online]. New York: United Nations. Available at: http://www.un.org/apps/news/story.asp/www.unaids. org/en $/ \mathrm{html} /$ story.asp?NewsID $=44911 \& \mathrm{Cr}=$ disaster $\&$ Cr1=risk [accessed 12 January 2014].

Warhurst, A. 2006. Disaster prevention: a role for business?. Geneva: International Federation of Red Cross and Red Crescent Societies, the ProVention Consortium, Maplecroft.

WDEM. 2001. New school building "hardened" against the wind [online]. Available at: http://emergencymanagement.wi.gov/mitigation/stories/hm-oakfield_success.pdf [accessed 10 February 2015]

Wedawatta, G. 2013. Resilience of construction SMEs to extreme weather events. $\mathrm{PhD}$ thesis, University of Salford, UK.

Wedawatta, G.; Ingirige, B.; Proverbs, D. 2014. Small businesses and flood impacts: the case of the 2009 flood event in Cockermouth, Journal of Flood Risk Management 7: 42-53. http://dx.doi.org/10.1111/jfr3.12031

Wieland, A.; Handfield, R. B. 2013. The socially responsible supply chain: an imperative for global corporations, Supply Chain Management Review 17: 22-29.

Zhang, J. 2012. Public-private-people-partnership (4P) for disaster preparedness, mitigation and post-disaster reconstruction. Master of Philosophy thesis, The University of Hong Kong, Hong Kong.

Zhang, J. Q.; Kumaraswamy, M. M. 2013. A publicprivate-people partnership (4P) approach for postdisaster reconstruction - with a case study of the post-earthquake reconstruction in Sichuan, China, in International Conference on Building Resilience 2013. Ahungalle, Sri Lanka.

Zhao, Z.-Y.; Zhao, X.-J.; Davidson, K.; Zuo, J. 2012. A corporate social responsibility indicator system for construction enterprises, Journal of Cleaner Production 29-30: 277-289. http://dx.doi.org/10.1016/j.jclepro.2011.12.036 